\title{
Cellulase Production by Aspergillus niger ATCC 16888 on Copra Waste from Coconut Milk Process In Layered Packed-bed Bioreactor
} \section{(1)}

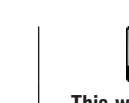

This work is licensed under a Creative Commons Attribution 4.0 International License doi: 10.15255/CABEQ.2017.1161

Original scientific paper Received: May 3, 2017 Accepted: May 23, 2018

\begin{abstract}
Solid-state fermentation (SSF) has been used to produce value-added products from agricultural and food processing wastes, but the majority of SSF production has been conducted on a small scale due to the limitations of heat and mass transfer. This research aimed to reduce the temperature changes in packed-bed bioreactor during the cellulase fermentation of Aspergillus niger ATCC 16888 on copra waste from coconut milk process. The three configurations of bioreactor used in this study consisted of one- (control), two- and three-layered packed-bed bioreactors. Total volumes of packed-bed bioreactor and bed material were 127 and $57 \mathrm{~L}$, respectively. The sterilized air $30{ }^{\circ} \mathrm{C}$ was forced from the bottom of bioreactor at $0.20 \mathrm{vvm}$. The highest cellulase production $(5.0 \pm 0.4$ FPU $g^{-1}$ DS was obtained from the bottom zone of the three-layered bioreactor after fermenting for $1 \mathrm{~d}$. However, the greatest growth was found at the top one, in which a large amount of aerial mycelium was detected.
\end{abstract}

Keywords:

cellulase, solid-state fermentation, packed-bed bioreactor, Aspergillus niger

\section{Introduction}

Nowadays, solid-state fermentation (SSF) is used to produce value-added bio-products from agro-industrial and food wastes, which contain carbohydrates and other nutrients for microbial metabolisms $^{1}$. There are many researchers studying SSF for enzyme production; for instance, protease $^{2}$, peroxidase $^{3}, \alpha$-amylase ${ }^{4}$, etc. Cellulase is an enzyme that can be produced by $\mathrm{SSF}^{5}$. Although both bacteria and fungi can produce cellulase, the filamentous fungi Aspergillus niger and Trichoderma reesei have been mostly used for commercial cellulase production $^{6}$. Recently, many microorganisms have been studied for cellulase production from different agricultural materials, such as soy residues ${ }^{7}$, babassu cake ${ }^{8}$, sugar cane bagasse ${ }^{9}$ and Palmyra palm ${ }^{10}$. Cerda et al. ${ }^{11}$ indicated that the microbial diversity benefited the economics of cellulase fermentation using wastes as substrates. However, filamentous fungi are most suitable for SSF because they can grow and carry out their metabolisms in low moisture conditions ${ }^{12}$.

Coconut, an economic crop of Thailand, has been used to produce many food products; for in-

"Corresponding author: E-mail address: teerin.ch@kmitl.ac.th, Tel: +66-2329-8356 Ext.12, Fax: +66-2329-8356 Ext.13 stance, coconut juice and coconut milk. In the process of coconut milk, copra waste was obtained up to $30 \%{ }^{13}$. To add value of this waste, a solid-state fermentation (SSF) process is attractive due to low production cost. Since copra waste contains high content of cellulose $\sim 72 \%{ }^{14}$, which is a good substrate for cellulose production by fungi ${ }^{15}$, this research focused on using copra waste as a solid substrate for a fungal cellulase production by SSF, because cellulolytic enzymes have been currently useful in many industries such as textile, paper, detergent, and energy industries ${ }^{16,17}$. However, most researchers into SSF have conducted experiments on the laboratory scale, such as flasks ${ }^{2,18-20}$, glass columns $^{21}$, plate bioreactor ${ }^{22}$, bag bioreactor ${ }^{23}$, etc. due to scale-up problems, especially the accumulation of heat generated by microbial respiration and other metabolisms ${ }^{24}$. One of the bioreactor types which is easy and cheap to operate is the packedbed bioreactor. However, the main problems in its application are the difficulties in parameter control, including temperature and moisture distribution within the bioreactor ${ }^{25,26}$ which is affected by porosity, bed height, and fluid velocity ${ }^{27}$. Recently, Biz et $a l .{ }^{28}$ indicated that the porosity of the substrate bed was an important factor for a temperature control of the packed-bed column and the problem found in the pilot-scale packed-bed bioreactor was heat ac- 
cumulation due to a compaction of the bed during the $\mathrm{SSF}^{29}$. Therefore, this work aimed to increase the heat removal from packed-bed bioreactor during the SSF of cellulase by $A$. niger by dividing the packed-bed into two and three layers, and determining its effect on the fungal growth and the cellulase production.

\section{Materials and methods}

\section{Bioreactor construction}

The 127-L packed-bed bioreactor $(45 \mathrm{~cm}$ diameter and $80 \mathrm{~cm}$ height) was used to ferment the $57-\mathrm{L}$ substrate in this research. The schematics of the packed-bed bioreactors used in this research are shown in Fig. 1. The aluminium screen baskets used as the substrate container were connected to the cylinder stainless steel frame. The diameter of the baskets for the control (CB), two-layered (2LB) and three-layered (3LB) bioreactors were $45 \mathrm{~cm}$, but their heights were different $-36 \mathrm{~cm}$ (1 basket), 18 $\mathrm{cm}$ ( 2 baskets) and $12 \mathrm{~cm}$ ( 3 baskets), respectively. After filling the substrate in the baskets, they were assembled to the frame. The positions of the baskets were adjustable along the height of the frame by screws. The $45.5 \mathrm{~cm}$ diameter aluminium cylinder (1.5 mm thickness) with holes and stoppers was made to cover the side and act as a wall of the bioreactor, which was able to collect the fermented sample and measure the temperature during SSF. An aluminium lid punctured for air was then used to cover the bioreactor. The bioreactor was connected to a rotary air pump (LP-20, Resun, China) at the bottom of the bioreactors for forcing air. The air ve- locity was controlled by gas rotameter (Model K-1011, Nitto Denko Corporation, Japan).

\section{Fungal strain and inoculum preparation}

The strain, Aspergillus niger ATCC 16888, was purchased from the American Type Culture Collection (ATCC) and treated according to the procedure provided by the ATCC. Its spore suspension was prepared by cultivating $A$. niger on PDA in 86-mm-diameter petri dish at $30^{\circ} \mathrm{C}$ for $7 \mathrm{~d}$, and collecting the spores using sterilized water. The suspension was filtrated using Whatman ${ }^{\mathrm{TM}}$ No.1 filter paper (GE Healthcare UK limited, China) under aseptic conditions. The concentration of spores in the suspension was adjusted to $10^{6}$ spores $\mathrm{mL}^{-1}$ by adding sterilized water.

\section{Solid substrate preparation}

Copra waste obtained from a local market was dried at $80{ }^{\circ} \mathrm{C}$ for $6 \mathrm{~h}$. It was packed in a closed container to prevent oxidations from air and light, and then kept at lower than $5{ }^{\circ} \mathrm{C}$. An amount of $5 \mathrm{~kg}$ of substrate containing $60 \%$ moisture was used for one batch of SSF. It was prepared by adding $2.8 \mathrm{~kg}$ distilled water into $2.0 \mathrm{~kg}$ dry copra waste, and autoclaved at $121{ }^{\circ} \mathrm{C}$ for $30 \mathrm{~min}$, and cooled to room temperature in an aseptic area. The sterilized substrate was inoculated and mixed with $200 \mathrm{~mL}$ spore suspension $\left(\sim 0.2 \mathrm{~kg}\right.$, total spore number $\left.=2-10^{8}\right)$ to achieve the $60 \%$ moisture content and $10^{5}$ spores $\mathrm{g}^{-1}$ dry substrate using a 50 -L horizontal rotary drum that was built to mix at $10 \mathrm{rpm}$ for $10 \min (\sim 15-20$ $\mathrm{L} / \mathrm{batch})$. The moisture content of substrate was measured using the moisture analyzer before the experiment.
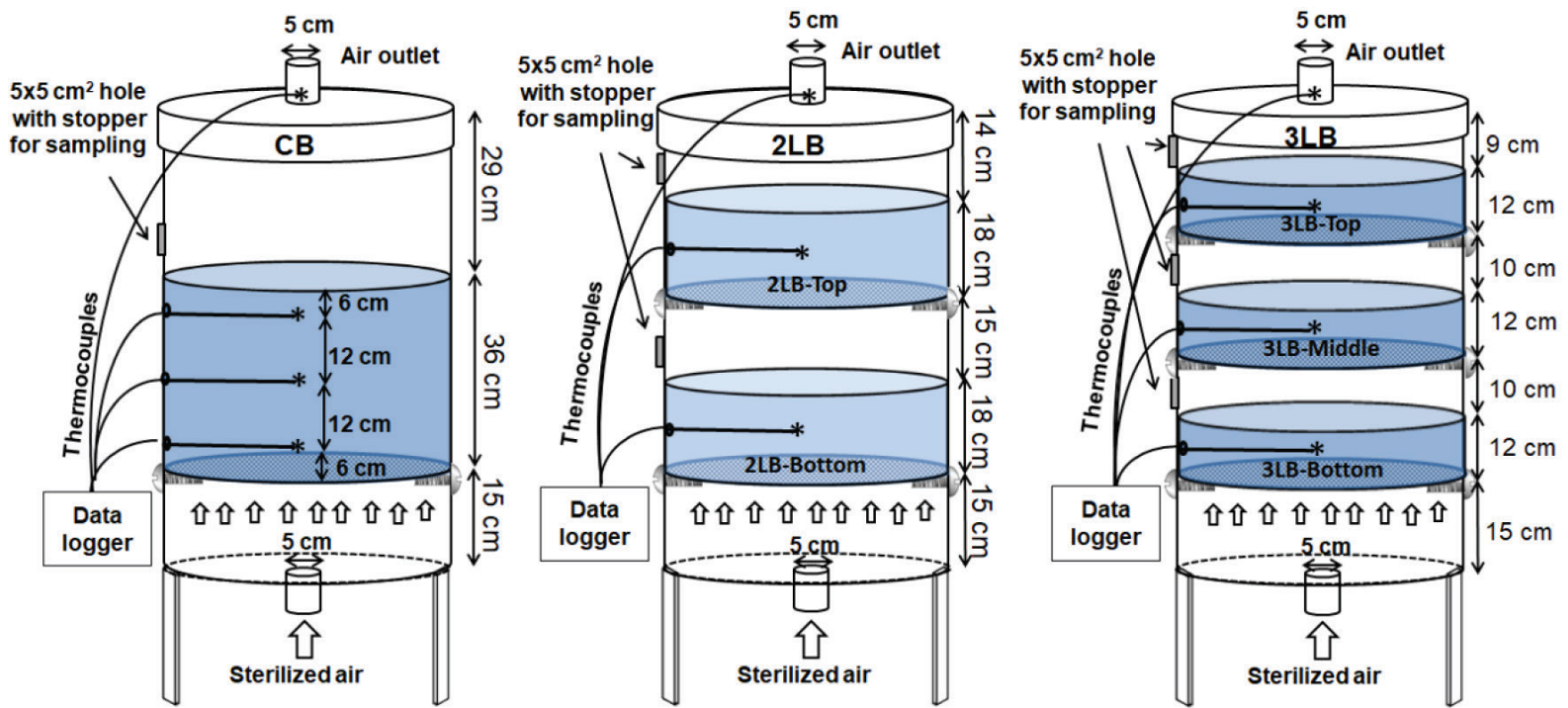

Fig. 1 - Schematics of packed-bed bioreactors used in this study (a) Control packed-bed bioreactor, CB; (b) Two-layered packedbed bioreactor, 2LB; (c) Three-layered packed-bed bioreactor, 3LB; The * symbols represent the positions for temperature measurement 


\section{Solid-state fermentation}

Five kg of prepared substrate mixed with spore suspension (total volume $=57 \mathrm{~L}$ ) was filled in the studied packed-bed bioreactors consisting of the $\mathrm{CB}, 2 \mathrm{LB}$, and $3 \mathrm{LB}$. Each bed in the 2LB contained $2.5 \mathrm{~kg}$ or $28.5 \mathrm{~L}$ of the prepared substrate. The same total weight and volume of bed was applied in the $3 \mathrm{LB}$, where each bed was filled with $1.7 \mathrm{~kg}$ or $19 \mathrm{~L}$ of the substrate. During 6 days of fermentation, the humidified air $\left(30^{\circ} \mathrm{C}\right)$ sterilized by the PTFE membrane (Millex ${ }^{\circledR}-\mathrm{FG}$, Millipore corporation, USA) was aerated from the bottom of bioreactor at a rate of $0.2 \mathrm{vvm}$ or $11.4 \mathrm{~L} \mathrm{~min}^{-1}$. The fermented sample was collected randomly (5 samples per bed) by puncturing the bed along the height of the bed using $1.0 \mathrm{~cm}$ diameter glass tube at intervals of $1 \mathrm{~d}$ to analyze moisture content by oven drying, cellulase activity by FPase assay, and fungal growth by glucosamine measurement. Each treatment was performed in triplicate. Temperatures of outlet air and beds in each layer were monitored during SSF using the thermocouples Type $\mathrm{T}$ (1.5 $\mathrm{mm}$ diameter) connected to the data logger (Model 34970A, Keysight Technologies, USA).

\section{Enzyme extraction}

Cellulase was extracted from the fermented sample according to the modified method of Ang et al. ${ }^{30}$ About $4 \mathrm{~g}$ fermented sample was soaked in 100 $\mathrm{mL}$ sodium acetate buffer $(\mathrm{pH} 6.5,0.05 \mathrm{M})$ at room temperature $\left(\sim 25^{\circ} \mathrm{C}\right)$, and stirred for $30 \mathrm{~min}$ with a magnetic stirrer. After filtrating through Whatman ${ }^{\mathrm{TM}}$ No.1 filter paper, the filtrate was used for FPase assay.

\section{Analysis}

\section{Glucosamine determination for fungal growth}

About $5 \mathrm{~g}$ of fermented sample was dried at 80 ${ }^{\circ} \mathrm{C}$ for $6 \mathrm{~h}$, then the amount of $10 \mathrm{mg}$ of dried fermented sample was hydrolyzed with $60 \%$ sulfuric acid solution, and the glucosamine content analyzed using a colorimetric method ${ }^{31}$ by measuring the absorbance of reaction solution at $650 \mathrm{~nm}$ with the UV-Visible spectrophotometer (Model Genesys 10S, Thermo Fisher Scientific, USA). The standard solution was prepared using $\mathrm{HCl}$-glucosamine solution with different concentrations. The growth of $A$. niger was reported as a glucosamine content in dry fermented copra waste $\left(\mathrm{mg} \mathrm{g}_{\mathrm{DS}}^{-1}\right)$. The analyses were performed in triplicate. The values of glucosamine content were plotted against the fermentation time, and their values in the growth phase were used to calculate the specific growth rate using exponential equation as in Eq. 1.

$$
X_{t}=X_{0} e^{\mu}
$$

where $X_{t}$ is the glucosamine content ( $\mathrm{mg} \mathrm{g}^{-1}$ sample) at time $\sim t, X_{0}$ is the glucosamine content $\left(\mathrm{mg} \mathrm{g}^{-1}\right.$ sample) at the initial time $(t=0)$, and $\mu$ is the specific growth rate $\left(\mathrm{d}^{-1}\right)$ in the growth phase.

\section{FPase assay}

Cellulase activity (FPA) was analyzed according to Ghose ${ }^{32}$. The amount of $0.5 \mathrm{~mL}$ crude enzyme and $1.0 \mathrm{~mL}(0.05 \mathrm{M})$ citrate buffer, $\mathrm{pH}$ 5.0, were added to test tubes containing $5 \mathrm{mg}$ of Whatman No.1 filter paper $\left(6 \times 1 \mathrm{~cm}^{2}\right)$. The test tube was incubated in a water bath at $50{ }^{\circ} \mathrm{C}$ for $1 \mathrm{~h}$. Then, 3 $\mathrm{mL}$ of 3, 5-dinitrosalicylic acid was added into the tube and boiled for 15 min to stop the reaction. After cooling to ambient temperature, its volume was filled to $10 \mathrm{~mL}$ by adding distilled water and the absorbance of the filtered solution measured at 540 $\mathrm{nm}$ wavelength against a blank of sugar-free sample using the UV-Visible spectrophotometer (Model Genesys 10S, Thermo Fisher Scientific, USA). Standard curve was conducted using a standard glucose solution with known concentration. One unit of enzyme activity (U) was the amount of enzyme that released one micromole of glucose in one minute. The FPase activity was reported as the unit of enzyme in one gram of dry substrate (FPU $\left.\mathrm{g}_{\mathrm{DS}}^{-1}\right)$.

\section{Results and discussion}

\section{Temperature distribution in packed-bed bioreactor}

During the SSF, the temperatures of each bed in the studied bioreactors were measured as shown in Fig. 2. The bed temperature in the $\mathrm{CB}$ increased from $30.0 \pm 0.5{ }^{\circ} \mathrm{C}$ at the beginning to the maximum of $52.0 \pm 3.0^{\circ} \mathrm{C}$ at day 1 and slowly decreased to $38.2 \pm 1.6{ }^{\circ} \mathrm{C}$ at day 6 . The increasing temperature also occurred in the study of Pitol et al. ${ }^{24}$, who found that the bed temperature increased up to 47 ${ }^{\circ} \mathrm{C}$ from $32{ }^{\circ} \mathrm{C}$ during the $\mathrm{SSF}$ of $A$. niger in $30 \mathrm{~kg}$ wheat bran substrate using the pilot-scale packedbed bioreactor (50 cm height). Casciatori and Frassatto $^{33}$ indicated that increasing aeration rate helped reduce the metabolic heat during the SSF, but the decreasing moisture content of the bed became a problem. The temperature at the center of the $\mathrm{CB}$ was higher than the lower and upper positions throughout the SSF. To decrease the bed temperature, the bed of the $\mathrm{CB}$ was divided into two and three beds as in the $2 \mathrm{LB}$ and $3 \mathrm{LB}$. The temperatures in both layers of the 2LB (2LB-Bottom and 2LB-Top) slightly decreased from that in the $\mathrm{CB}$. The highest temperature in the 2LB-Bottom and 2LB-Top were 

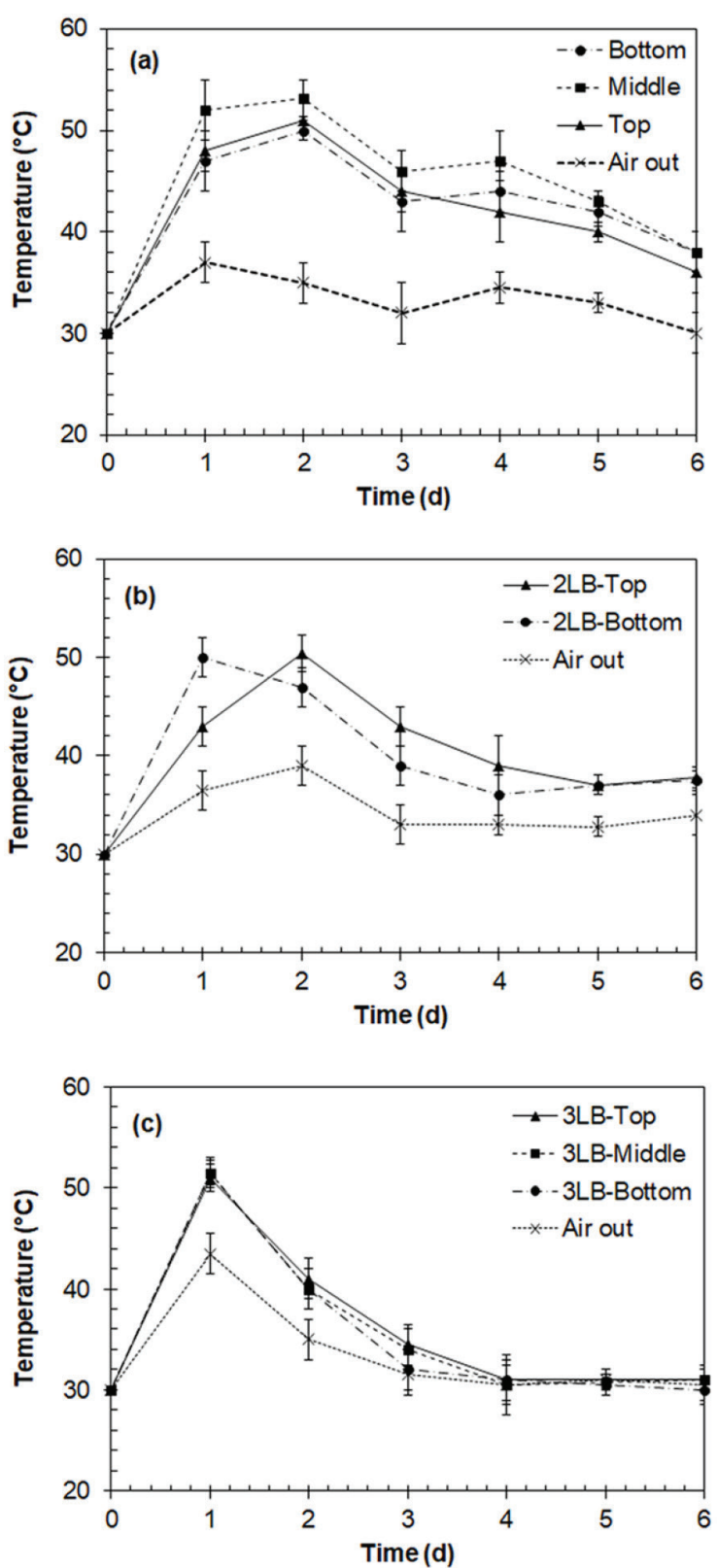

Fig. 2 - Temperatures of beds and outlet air during SSF of A. niger (a) Control packed-bed bioreactor, $C B$; (b) Two-layered packed-bed bioreactor, 2LB; (c) Three-layered packed-bed bioreactor, $3 L B$

$48.7 \pm 0.8^{\circ} \mathrm{C}$ at day 1 , and $50.4 \pm 1.9^{\circ} \mathrm{C}$ at day 2 , and reduced to $37.5 \pm 0.8^{\circ} \mathrm{C}$ and $37.8 \pm 1.1^{\circ} \mathrm{C}$ at day 6 , respectively. For the $3 \mathrm{LB}$, it was found that all temperatures of the three beds were quite similar. The temperature of each bed in the 3LB measured at day 1 changed from $30.0 \pm 0.5{ }^{\circ} \mathrm{C}(t=0 \mathrm{~d})$ to $51.5 \pm 1.5,51.5 \pm 1.2$ and $51.3 \pm 1.0^{\circ} \mathrm{C}$ for the 3LB-Bottom, -Middle and -Top, respectively. From all studied packed-bed bioreactors, the maximum temperatures were around $50{ }^{\circ} \mathrm{C}$ at day 1 , except that of the 2LB-Top, which increased up to day 2 . The greatest reduction rate of temperature (highest slope of decreasing temperature in Fig. 2(c)) was detected in the $3 \mathrm{LB}$. It was found that more heat in the 3LB was removed by flowing air, since the highest temperature of its outlet air $\left(43.5 \pm 2.1{ }^{\circ} \mathrm{C}\right)$ was higher than that of the $\mathrm{CB}\left(37.0 \pm 1.5^{\circ} \mathrm{C}\right)$ and the $2 \mathrm{LB}\left(39.1 \pm 1.9^{\circ} \mathrm{C}\right.$ at day 2$)$. This indicated that dividing the packed bed had increased heat removal in the packed-bed bioreactor due to a reduction in bed compaction.

\section{Growth of $A$. niger}

The fungal growth of $A$. niger, shown in Fig. 3, is reported as glucosamine content in fermented substrate. The highest glucosamine content of the sample from the culture in the $\mathrm{CB}$ was found on day 2 as $76.9 \pm 11.5 \mathrm{mg} \mathrm{g}^{-1}$, which means its specific growth rate in $0-1 \mathrm{~d}$ was $7.7 \mathrm{~d}^{-1}$. The growth phase changed to stationary after day 2. For SSF in the $2 \mathrm{LB}$, the fungal growth separately measured in each layer showed that the maximum glucosamine contents in the fermented samples were detected on day 2 as $73.9 \pm 8.6$ and $84.2 \pm 5.9 \mathrm{mg} \mathrm{g}^{-1}$, ; however, their growth phases from $0-1 \mathrm{~d}$ showed the specific growth rates as 7.1 and $8.3 \mathrm{~d}^{-1}$ for the 2LB-Bottom and -Top, respectively. The characteristics of growth curves obtained from the lower (2LB-Bottom) and upper (2LB-Top) beds of the two-layered bioreactor were similar to that of the CB. The highest glucosamine content in the fermented samples from the control was not significantly different from both layers of the 2LB. The different fungal growth in different layers of the bioreactor was clearly present in the 3LB, as shown in Fig. 3(c). The maximum glucosamine contents in the cultures of each bed of the $3 \mathrm{LB}$ were $33.3 \pm 3.7 \mathrm{mg} \mathrm{g}^{-1}$ at day 1 , $62.4 \pm 6.8 \mathrm{mg} \mathrm{g}^{-1}$ at day 2 and $67.4 \pm 5.4 \mathrm{mg} \mathrm{g}^{-1}$ at day 1 for the 3LB-Bottom, 3LB-Middle and 3LBTop, respectively. The highest specific growth rate found in the 3LB was $8.8 \mathrm{~d}^{-1}$ analyzed from the 3LB-Top. Even if the maximum glucosamine contents in the fermented samples from the 3LB-Bottom and -Middle were different, their specific growth rates were similar as $8.1 \mathrm{~d}^{-1}$.

Obviously, a higher amount of aerial mycelium, observed by white color of $A$. niger mycelium, was found in the higher bed position of bioreactor including the top of the CB, the 2LB-Top and the 3LB-Top. Therefore, the large amount of glucosamine in the samples cultured on the higher position of the bioreactor might be due to the growth of aerial mycelium of $A$. niger. As a role of aerial mycelium related to oxygen supply ${ }^{34-36}$, it could be implied that low partial pressure of oxygen occurring at the top of bioreactor enhanced aerial mycelium generation in order to increase oxygen supply.

The results of the bed temperatures in Fig. 2 show the direct correlation between bed temperature and fungal growth. When the temperature reached around $50{ }^{\circ} \mathrm{C}$, the growth stopped and then 

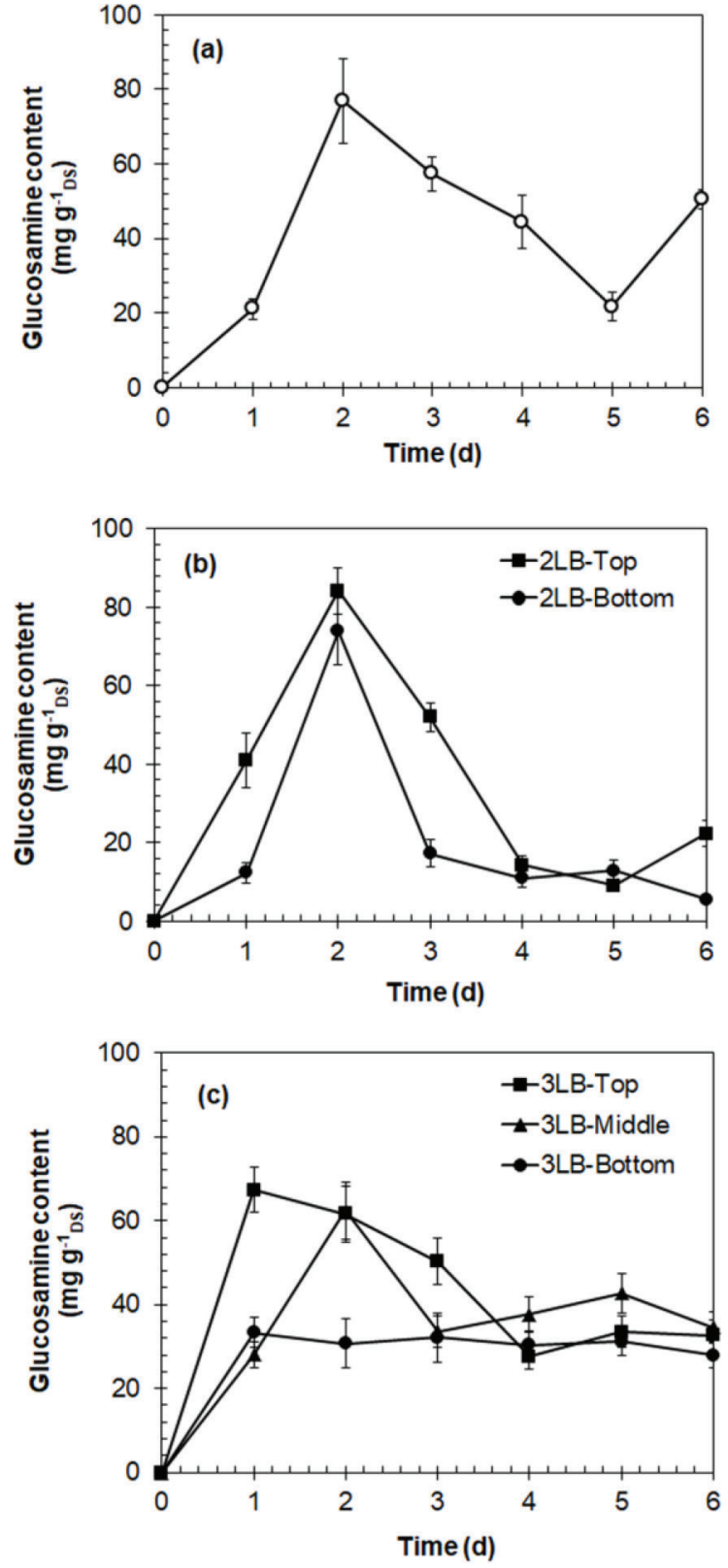

Fig. 3-Glucosamine contents in fermented substrate. The glucosamine contents represent the fungal growth (a) Control packed-bed bioreactor, CB; (b) Two-layered packed-bed bioreactor, 2LB; (c) Three-layered packed-bed bioreactor, 3LB.

decreased (death phase), because the fungal hyphal branching decreased at the temperature higher than $45^{\circ} \mathrm{C}^{37}$. After the growth had stopped, the temperature of all beds decreased due to a decrease in heat generation from fungal respiration ${ }^{38}$. The decrease in glucosamine content indicated self-degradation of fungi, where the fungal cell was destroyed by many fungal self-produced enzymes, including cellulase ${ }^{39}$. The glucosamine obtained from a degradation of chitin was used as carbon and nitrogen sources for the next generation of $A$. niger. Moreover, the new spores of $A$. niger were detected in
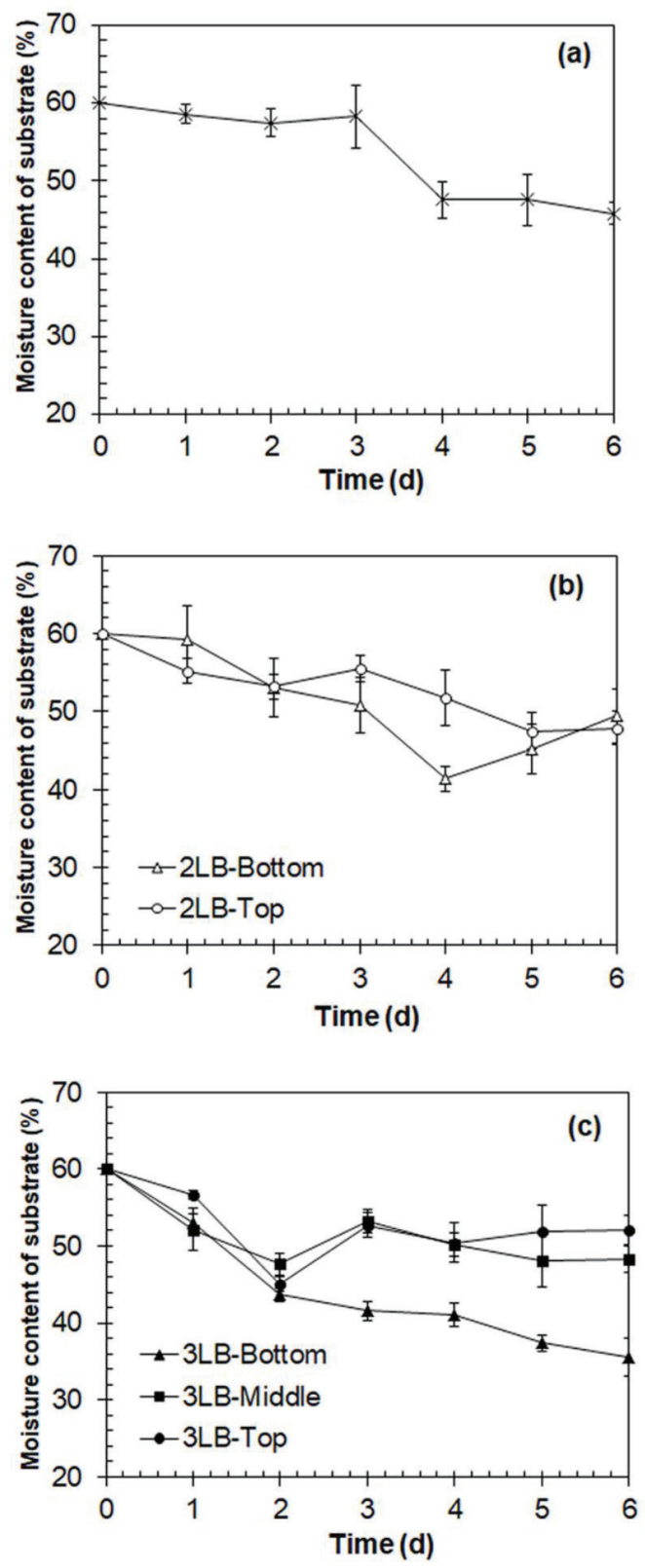

Fig. 4 - Moisture contents of fermented substrate (a) Control packed-bed bioreactor, CB; (b) Two-layered packed-bed bioreactor, 2LB; (c) Three-layered packed-bed bioreactor, $3 L B$

the substrate on days 4-5 causing increased content of glucosamine on day 6 .

In addition, the fungal growth without the degradation of glucosamine was only found in the SSF at the 3LB-Bottom due to low moisture content of substrate, which was unsuitable for its growth and metabolisms. Selvakumar et al. ${ }^{40}$ also reported that the optimum initial moisture content for the growth of $A$. niger on tea waste was about $60 \%$, and found that the growth decreased when initial moisture content was lower than $45 \%$. Moreover, a reduction in moisture content of the substrate affected the 

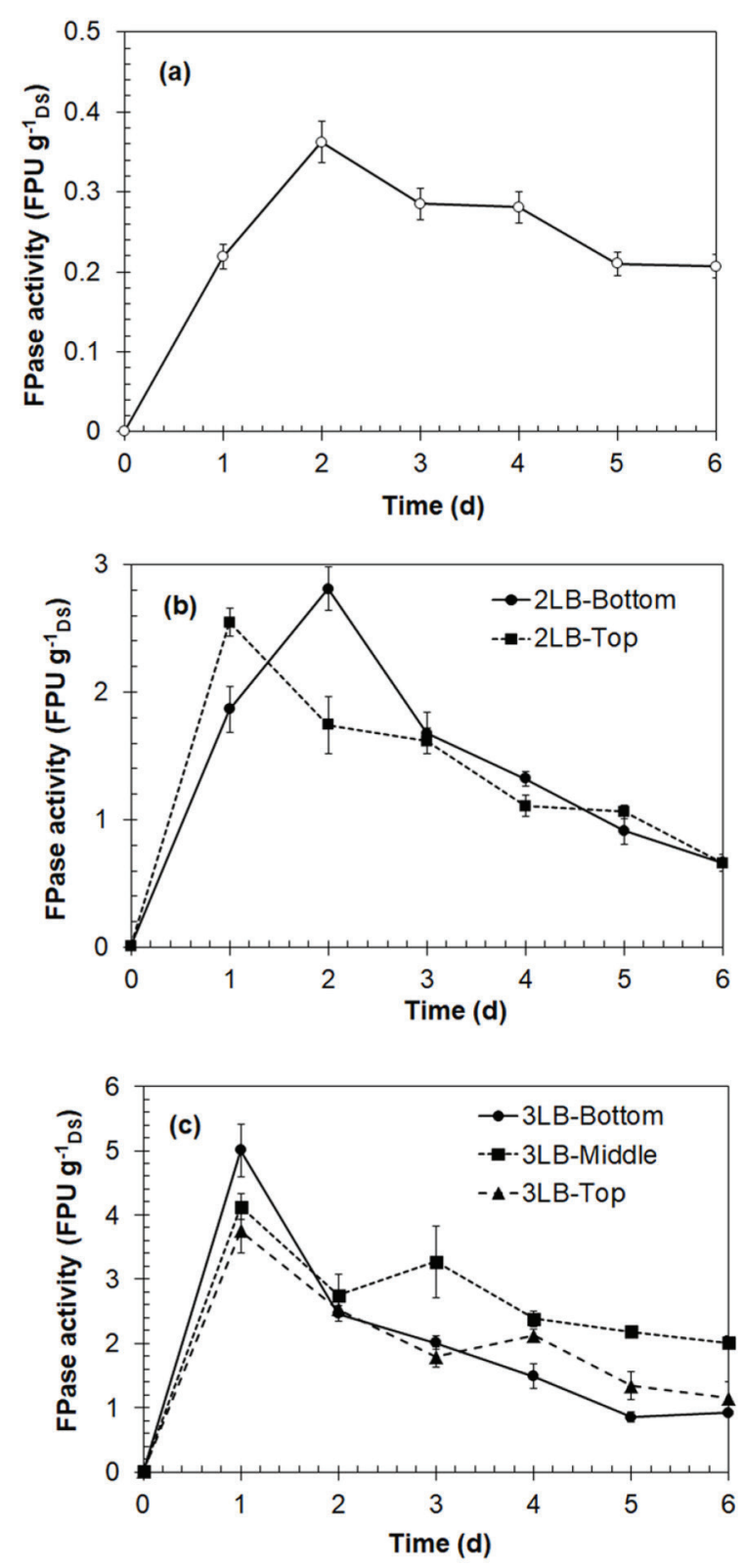

Fig. 5 - Cellulase production of A. niger in the SSF (a) Control packed-bed bioreactor, CB; (b) Two-layered packed-bed bioreactor, 2LB; (c) Three-layered packed-bed bioreactor, $3 L B$

oxygen and nutrient transfers during the $\mathrm{SSF}^{41}$. As shown in Fig. 4, the lower moisture content of substrate was found at the layer near the bottom because the aeration was forced at the bottom of bioreactor leading to moisture transfer from the bottom bed to the top bed of bioreactor.

\section{Cellulase (FPase) activity}

The cellulase production of $A$. niger shown in Fig. 5 suggests that the maximum FPase activity obtained from the CB was only $0.36 \pm 0.03 \mathrm{FPU} \mathrm{g}^{-1}{ }_{\mathrm{DS}}$ at day 2, while that in the 2LB-Bottom and -Top were higher, i.e., $2.81 \pm 0.22$ and $2.55 \pm 0.18$ FPU $\mathrm{g}^{-1}$, respectively. Even if the FPase activity mea- sured from the bed of the 2LB-Bottom was significantly higher than that of the 2LB-Top, the time to reach the maximum value was delayed $1 \mathrm{~d}$. According to the temperature results presented in Fig. 2, the FPase activity corresponded to the change in bed temperature. When the bed temperature increased to $50{ }^{\circ} \mathrm{C}$, which was the maximum value, the FPase activity in the fermented samples decreased. This phenomenon also occurred in the 3LB. The highest FPase activity in the $3 \mathrm{LB}$ was detected in the 3LB-Bottom as $5.01 \pm 0.41 \mathrm{FPU} \mathrm{g}^{-1}{ }_{\mathrm{DS}}$ followed by that in the 3LB-Middle and the 3LBTop as $4.13 \pm 0.21$ and $3.75 \pm 0.34 \mathrm{FPU} \mathrm{g}^{-1}$ ${ }_{\mathrm{DS}}$, respectively. The results obtained from the $3 \mathrm{LB}$ clearly showed that the highest cellulase production was obtained in the bottom layer, higher than that in the middle and top layers. Since the aeration was forced from the bottom of bioreactor, the air in the bottom zone contained a higher oxygen concentration, which reduced along the height of bioreactor due to fungal respiration utilizing oxygen. This showed the importance of oxygen for cellulase production. Even if the highest biomass production was detected at the top of the bioreactor, the highest cellulase production was found at the bottom. This might be because the aerial mycelium did not support the cellulase production. These results are in agreement with the work of Rahardjo et al. ${ }^{36}$, indicating that the secretion of the enzyme increased in the cultivation without aerial mycelium. Dividing substrate bed into many layers reduced the compactness of bed caused by the mass of upper bed, leading to an increase in the possibility of fungi contacting oxygen in forced air.

\section{Conclusion}

Copra waste from coconut milk processing was a good substrate for cellulase fermentation by $\mathrm{A}$. $n i$ ger. The most important factors were the controls of bed temperature, water migration, and oxygen concentration. Using a multi-layer packed-bed bioreactor helped increase the heat removal, and consequently, the cellulase production increased. The quality of air forced through the bed along the packed bed should be adjusted in order to obtain higher production yield of cellulase from all layers of a multi-packed-bed bioreactor. The thickness of the bed should be considered to relate with the temperature and moisture uniformity, as well as oxygen partial pressure.

\section{ACKNOWLEDGEMENT}

This work was supported by King Mongkut's Institute of Technology Ladkrabang [2560A11802042]. 


\section{References}

1. Manan, M. A., Webb, C., Modern microbial solid state fermentation technology for future biorefineries for the production of added-value products, Biofuel Res. J. 16 (2017) 730 . doi: https://doi.org/10.18331/BRJ2017.4.4.5

2. Novelli, P. K., Barros, M. M., Fleuri, L. F., Novel inexpensive fungi proteases: Production by solid state fermentation and characterization, Food Chem. 198 (2016) 119. doi: https://doi.org/10.1016/j.foodchem.2015.11.089

3. Palma, C., Lloret, L., Sepulveda, L., Contreras, E., Production of versatile peroxidase from Pleurotus eryngii by solid-state fermentation using agricultural residues and evaluation of its catalytic properties, Prep. Biochem. Biotechnol. 46 (2016) 200. doi: https://doi.org/10.1080/10826068.2015.1084513

4. Mahmood, S., Shahid, M. G., Nadeem, M., Irfan, M., Syed, Q., Production and optimization of $\alpha$-amylase from Aspergillus niger using potato peel as substrate, Pak. J. Biotechnol. 13 (2016) 101.

5. Sukumaran, R. K., Singhania, R. R., Pandey, A., Microbial cellulases - production, applications and challenges, J. Sci. Ind. Res. 64 (2005) 832.

6. Yoon, L. W., Ang, T. N., Ngoh, G. C., Chua, A. S. M., Fungal solid-state fermentation and various methods of enhancement in cellulase production, Biomass Bioenerg. 67 (2014) 319 .

doi: https://doi.org/10.1016/j.biombioe.2014.05.013

7. Heck, J. X., Hertz, P. F., Ayub, M. A. Z., Cellulase and xylanase production by isolated amazon Bacillus strains using soybean industrial residue based solid-state cultivation, Braz. J. Microbiol. 33 (2002) 213. doi: https://doi.org/10.1590/S1517-83822002000300005

8. Castro, A. M., Castilho, L. R., Freire, D. M. G., Performance of a fixed-bed solid-state fermentation bioreactor with forced aeration for the production of hydrolases by Aspergillus awamori, Biochem. Eng. J. 93 (2015) 303. doi: https://doi.org/10.1016/j.bej.2014.10.016

9. Long, C., Ou, Y., Guo, P., Li, Y., Cui, J., Long, M., Hu, Z., Cellulase production by solid state fermentation using bagasse with Penicillium decumbens L-06, Ann. Microbiol. 59 (2009) 517.

doi: https://doi.org/10.1007/BF03175140

10. Roopa, R., Charulatha, M., Meignanalakshmi, S., Production of cellulase from Bacillus subtilis under solid-state fermentation using fiber wastes of palmyra palm, Int. J. Curr. Microbiol. App. Sci. 6 (2017) 2225. doi: https://doi.org/10.20546/ijcmas.2017.606.264

11. Cerda, A., Gea, T., Vargas-Garcia, M. C., Sanchez, A., Towards a competitive solid state fermentation: Cellulases production from coffee husk by sequential batch operation and role of microbial diversity, Sci. Total Environ. 589 (2017) 56 . doi: https://doi.org/10.1016/j.scitotenv.2017.02.184

12. Bhargav, S., Sanjrani, M. A., Javed, S., Solid-state fermentation: An overview, Chem. Biochem. Eng. Q. 22 (2008) 49.

13. Raghavarao, K. S. M. S., Raghavendra, S. N., Rastogi, N. K. Potential of coconut dietary fiber, Coconut J. 51 (2008) 2.

14. Ng, S. P., Tan, C. P., Lai, O. M., Long, K., Mirhosseini, H., Extraction and characterization of dietary fiber from coconut residue, J. Food Agric. Environ. 8 (2010) 172.

15. Gautam, S. P., Bundela, P. S., Pandey, A. K., Jamaluddin, Awasthi, M., Sarsaiya, S., Optimization of the medium for the production of cellulase by the Trichoderma viride using submerged fermentation, Int. J. Environ. Sci. 1 (2010) 656.
16. Duan, X. Y., Liu, S. Y., Zhang, W. C., Zhang, Q. X., Gao, P. $J$., Volumetric productivity improvement for endoglucanase of Trichoderma pseudokoingii S-38, J. Appl. Microbiol. 96 (2004) 772 . doi: https://doi.org/10.1111/j.1365-2672.2004.02204.x

17. Kuhad, R. C., Gupta, R., Singh, A., Microbial cellulases and their industrial applications, Enzyme Res. 2011 (2011) 1. doi: https://doi.org/10.4061/2011/280696

18. Krishna, $C$., Production of bacterial cellulases by solid state bioprocessing of banana wastes, Bioresource Technol. 69 (1999) 231. doi: https://doi.org/10.1016/S0960-8524(98)00193-X

19. Sun, H. Y., Li, J., Zhao, P., Peng, M., Banana peel: A novel substrate for cellulase production under solid-state fermentation, Afr. J. Biotechnol. 10 (2011) 17887.

20. Zhao, S. H., Liang, X. H., Hua, D. L., Ma, T. S., Zhang, H. $B$., High-yield cellulose production in solid-state fermentation by Trichoderma reesei SEMCC-3.217 using water hyacinth (Eichhornia crassipes), Afr. J. Biotechnol. 10 (2011) 10178. doi: https://doi.org/10.5897/AJB10.748

21. Deshpande, S. K., Bhotmange, M. G., Chakrabarti, T., Shastri, P. N., Production of cellulase and xylanase by Trichoderma reesei (QM 9414 mutant), Aspergillus niger and mixed culture by solid state fermentation (SSF) of water hyacinth (Eichhornia crassipes), Indian J. Chem. Techn. 15 (2008) 449.

22. Umsza-Guez, M. A., Díaz, A. B., de Ory, I., Blandino, A., Gomes, E., Caro, I., Xylanase production by Aspergillus awamori under solid state fermentation conditions on tomato pomace, Braz. J. Microbiol. 42 (2011) 1585. doi: https://doi.org/10.1590/S1517-83822011000400046

23. De la Cruz-Quiroz, R., Roussos, S., Hernandez-Castillo, D., Hernandez-Castillo, R., Itzel López-López, L., Castillo, F., Noé Aguilar, C., Solid-state fermentation in a bag bioreactor: Effect of corn cob mixed with phytopathogen biomass on spore and cellulase production by Trichoderma asperellum, in Faustino Jozala, A. (Ed.), Fermentation processes, InTech open Publ., 2017, pp 44-56.

doi: https://doi.org/10.5772/64643

24. Ghildyal, N. P., Gowthaman, M. K., Rao, K. S., Karanth, N. $G$., Interaction between transport resistances with biochemical reaction in packed bed solid-state fermentors: Effect of temperature gradients, Enzyme Microb. Technol. 16 (1994) 253. doi: https://doi.org/10.1016/0141-0229(94)90051-5

25. Ashley, V. M., Mitchell, D. A., Howes, T., Evaluating strategies for overcoming overheating problems during solid-state fermentation in packed bed bioreactors, Biochem. Eng. J. 3 (1999) 141. doi: https://doi.org/10.1016/S1369-703X(99)00010-8

26. Oliveira, F., Salgado, J. M., Abrunhosa, L., Perez-Rodrlguez, N., Dominguez, J., Venancio, A., Belo, I., Optimization of lipase production by solid-state fermentation of olive pomace: From flask to laboratory-scale packed-bed bioreactor, Bioprocess Biosyst. Eng. 40 (2017) 1123. doi: https://doi.org/10.1007/s00449-017-1774-2

27. Geankoplis, C. L., Transport processes and separation process principles (Includes unit operations), Prentice-Hall, New Jersey, 2003, pp 114-174.

28. Biz, A., Finkler, A. T. J., Pitol, L. O., Medina, B. S., Krieger, N., Mitchell, D. A., Production of pectinases by solid-state fermentation of a mixture of citrus waste and sugarcane bagasse in a pilot-scale packed-bed bioreactor, Biochem. Eng. J. 115 (2016) 54. doi: https://doi.org/10.1016/j.bej.2016.03.007 
29. Pitol, L. O., Biz, A., Mallmann, E., Krieger, N., Mitchell, D. $A$., Production of pectinases by solid-state fermentation in a pilot-scale packed-bed bioreactor, Chem. Eng. J. 283 (2016) 1009 doi: https://doi.org/10.1016/j.cej.2015.08.046

30. Ang, S. K., Shaza, E. M., Adibah, Y., Suraini, A. A., Madihah, M. S., Production of cellulase and xylanase by Aspergillus fumigatus SK1 using untreated oil palm trunk through solid state fermentation, Process Biochem. 48 (2013) 1293. doi: https://doi.org/10.1016/j.procbio.2013.06.019

31. Chysirichote, T., Takahashi, R., Asami, K., Ohtaguchi, K., Quantification of the glucosamine content in the filamentous fungus Monascus ruber cultured on solid surfaces, J. Basic Microbiol. 54 (2004) 350. doi: https://doi.org/10.1002/jobm.201200350

32. Ghose, T. K., Measurement of cellulase activities, Pure Appl. Chem. 59 (1987) 257. doi: https://doi.org/10.1351/pac198759020257

33. Casciatori, F. P., Casciatori, P. A., Thoméo, J. C., Cellulase production in packed bed bioreactor by solid-state fermentation, in $21^{\text {st }}$ European Biomass Conference and Exhibition Proceedings (2013) 1539.

34. Rahardjo, Y. S. P., Weber, F. J., Le Comte, E. P., Tramper, J., Rinzema, A., Contribution of aerial hyphae of Aspergillus oryzae to respiration in a model solid-state fermentation system, Biotechnol. Bioeng. 8 (2002) 539 doi: https://doi.org/10.1002/bit.10222

35. Rahardjo, Y. S. P., Korona, D., Haemers, S., Weber, F. J., Tramper, J., Rinzema, A., Limitations of membrane cultures as a model solid-state fermentation system, Lett. Appl. Microbiol. 39 (2004) 504.

doi: https://doi.org/10.1111/j.1472-765X.2004.01614.x
36. Rahardjo, Y. S. P., Weber, F. J., Haemers, S., Tramper, J., Rinzema, A., Aerial mycelia of Aspergillus oryzae accelerate $\alpha$-amylase production in model solid-state fermentation system, Enzym. Microb. Tech. 36 (2005) 900. doi: https://doi.org/10.1016/j.enzmictec.2005.01.010

37. Ordaz-Hernández, A., Ortega-Sánchez, E., Montesinos-Matias, R., Hernández-Martínez, R., Torres-Martínez, D., Loera, O., Morphological and enzymatic response of the thermotolerant fungus Fomes sp. EUM1 in solid state fermentation under thermal stress, FEMS Microbiol. Lett. 363 (2016) 1. doi: https://doi.org/10.1093/femsle/fnw177

38. Maier, R. M., Gentry, T. J., Physiological methods, in Pepper, I. L., Gerba, C. P., Gentry, T. J. (Eds.), Environmental Microbiology (Third edition), Elsevier Inc., California, 2015, pp 213-244. doi: https://doi.org/10.1016/B978-0-12-394626-3.00011-9

39. Hartl, L., Zach, S., Seidl-Seiboth, V., Fungal chitinases: Diversity, mechanistic properties and biotechnological potential, Appl. Microbiol. Biotechnol. 93 (2012) 533. doi: https://doi.org/10.1007/s00253-011-3723-3

40. Selvakumar, P., Ashakumary, L., Pandey, A., Biosynthesis of glucoamylase from Aspergillus niger by solid-state fermentation using tea waste as the basis of a solid substrate, Bioresource Technol. 65 (1998) 83. doi: https://doi.org/10.1016/S0960-8524(98)00012-1

41. Bastos, R. G., Morais, D. V., Volpi, M. P. C., Influence of solid moisture and bed height on cultivation of Aspergillus niger from sugarcane bagasse with vinasse, Braz. J. Chem. Eng. 32 (2015) 377. doi: https://doi.org/10.1590/0104-6632.20150322s00003423 